\title{
GCU
}

Glasgow Caledonian

University

University for the Common Good

\section{Understanding healthcare social enterprises: a new public governance perspective} Chandra, Yanto; Shang, Liang; Roy, Michael J.

Published in:

Journal of Social Policy

DOI:

$10.1017 / S 0047279421000222$

Publication date:

2022

Document Version

Author accepted manuscript

Link to publication in ResearchOnline

Citation for published version (Harvard):

Chandra, Y, Shang, L \& Roy, MJ 2022, 'Understanding healthcare social enterprises: a new public governance perspective', Journal of Social Policy, vol. 51, no. 4, pp. 834-855. https://doi.org/10.1017/S0047279421000222

\section{General rights}

Copyright and moral rights for the publications made accessible in the public portal are retained by the authors and/or other copyright owners and it is a condition of accessing publications that users recognise and abide by the legal requirements associated with these rights.

Take down policy

If you believe that this document breaches copyright please view our takedown policy at https://edshare.gcu.ac.uk/id/eprint/5179 for details of how to contact us. 
Understanding Healthcare Social Enterprises: A New Public Governance Perspective

\author{
Yanto Chandra * \\ Department of Applied Social Sciences \\ Centre for Social Policy and Social Entrepreneurship \\ The Hong Kong Polytechnic University, Kowloon, Hong Kong \\ Email: yanto.chandra@polyu.edu.hk \\ http://orcid.org/0000-0003-1083-5813 \\ Liang Shang \\ Department of Social Work \\ Chinese University of Hong Kong, Hong Kong \\ Email: dj2echo@gmail.com \\ https://orcid.org/0000-0002-8962-7226 \\ Michael J. Roy \\ Yunus Centre for Social Business and Health, \\ Glasgow Caledonian University, \\ Glasgow, United Kingdom \\ Email: Michael.Roy@gcu.ac.uk \\ https://orcid.org/0000-0002-1834-0826 \\ *Corresponding Author
}

Accepted for publication on 1 February 2021 in the Journal of Social Policy

Author final pre-print version 
Yanto Chandra $\mathrm{PhD}$ is Associate Professor in the Department of Applied Social Sciences, The Hong Kong Polytechnic University, and Founding Director of the Centre for Social Policy and Social Entrepreneurship (CSPSE). His research focuses on social entrepreneurship, impact investing, sustainable entrepreneurship, and policy. He is Associate Editor in Journal of Social Entrepreneurship, Social Enterprise Journal, and Business Ethics, The Environment and Responsibility and sits in various editorial boards in other journals. His work has been published in Public Management Review, Public Administration Review, Journal of Social Policy, American Review of Public Administration, World Development, Journal of Business Venturing, Journal of International Business Studies, among others.

Liang Shang $\mathrm{PhD}$ is a Postdoctoral Fellow in the Department of Social Work, Chinese University of Hong Kong. Her research focuses on social entrepreneurship, non-profit organisations and civil society. Her work has been published in Voluntas, International Social Work, and Third Sector Review, among others. Email: dj2echo@gmail.com.

Michael J. Roy $\mathrm{PhD}$ is Professor of Economic Sociology and Social Policy at the Yunus Centre for Social Business and Health and Glasgow Caledonian University, Glasgow, UK. His primary area of research concerns social enterprise and other 'alternative' economic forms. Professor Roy is Editor-in-Chief of Social Enterprise Journal, Associate Editor of Journal of Social Entrepreneurship. His work has been published in Public Management Review, Social Science and Medicine, Health Promotion International, Social Policy and Administration, among others. 


\title{
Understanding Healthcare Social Enterprises: A New Public Governance Perspective
}

\begin{abstract}
In recent years 'social enterprises' have become important partners in the delivery of key public services such as healthcare. However, little is known about how healthcare social enterprises contribute to public service provision in the health sector. We analyzed 172 social enterprises from four continents involved in healthcare to assess the types of interventions, processes, and roles they play responding to rapidly evolving healthcare systems. We found that they are engaged broadly in three dimensions of health service provision: improving access to health services; improving the quality of health services; and building public health capacity. We contribute to social policy theory by enhancing understanding of the micro-level interventions of social enterprises in the healthcare sector and articulating new dimensions of NPG that include co-innovation, co-lobbying, and co-integration in the context of healthcare.
\end{abstract}

Keywords: social enterprise, healthcare, health, intervention, New Public Governance 


\section{Introduction}

Healthcare has become an increasingly complex and intricate policy area and the recent responses precipitated by the COVID-19 outbreak have strained health systems worldwide, raising concerns about the capacity of public health systems to respond to the virus. Reassuringly, we have also witnessed a wave of solidarity, mutual aid, and collaborative efforts initiated by civil society actors and grassroots innovators to generate community-based responses, such as producing locally made hand sanitizers and supporting local workers and families most affected by the virus. A global health emergency like the COVID-19 pandemic has revealed an urgent need for a profound re-examination of the ways in which health and healthcare are organised and managed, involving the public, private and third sectors to tackle health and social care issues. Under these circumstances, New Public Governance (NPG), which has highlighted the increasing involvement and engagement of civil society actors in policy and service delivery (Jenson, 2017; Mendell, 2010), has become an important lens through which the management of public services, in the era of collaborative governance, can be understood (Osborne, 2010; Lindsay et al., 2014).

In recent years, there has been an increasing interest in the role of social enterprises ${ }^{1}-$ a type of enterprise that seeks to create public benefits (e.g., Chandra and Paras, 2020;

\footnotetext{
${ }^{1}$ There is no single definition for 'social enterprise' as the field lacks a unifying paradigm and the boundaries are fuzzy. In the business literature, social enterprise is characterized as hybrid organization that combines social and commercial logics (Battilana \& Lee, 2014). In social work and non-profit studies, it is also defined as social work and non-profits embracing business practices (Eikenberry \& Kluver, 2004; Gray et al., 2003). In development studies, it is defined as an alternative development model (Venot, 2016). In public administration, it is seen as hybrid organization that mixes the characteristics of the state, market and civil society (Brandsen and Karre, 2011). In political science, it has been seen as a tool to enact social change (Ganz et al., 2018). Hoogendoorn et al (2012) has offered a rich analysis of the different schools of thoughts in social entrepreneurship: The American School (innovation vs enterprise school) and the EMES and UK approaches. While there are no strict boundaries between them, they all share common characteristics, which is the emphasis on creating social value (Hoogendoorn et al., 2012). Social enterprises have been financed and established by individuals, non-profits, for-profit companies, as well as governments.
} 
Defourny and Nyssens, 2010; Kerlin, 2013; Mendell, 2010; Roy et al., 2013) using business strategies. While social enterprises operate in various fields of work, they have played an increasingly significant role in the provision of healthcare services (Mazzei et al., 2019; Miller et al., 2012). In this article, we use the term healthcare social enterprises (HCSEs) to refer to those social enterprises that work primarily in the provision of healthcare. With an increasing emphasis on inter-organisational relations in policy delivery embedded within the NPG approach, HCSE has been framed as an ideal civil society business model that can provide alternative and effective ways to deliver healthcare services and, in places where the state has traditionally provided the majority of healthcare services, can compensate for the withdrawal of the state somewhat from direct welfare provision through community-based action (Macaulay et al., 2018).

However, despite an increasing interest in the promise of HCSE in engaging a collaborative approach to influence health services production and delivery under the NPG framework (Barraket and Yousefpour, 2013), there is a dearth of understanding of what HCSEs actually do (i.e., their 'interventions' - see Craig et al., 2008) and the nature of their collaborative relationships with other actors, especially the public sector, in these processes. The few articles on social enterprise in relation to health have been primarily conceptual (e.g., Ferguson, 2012; Roy et al., 2014; Roy et al., 2018) or have used a case study approach with single or a few cases, in which the findings offer limited insights into larger number of cases or wider contexts (e.g., Macaulay et al., 2018; Farmer et al., 2016). Very little research has examined the contributions of HCSEs in the cross-sectoral and inter-organisational deliberations within the public sphere from the perspective of NPG. In other words: to date, we know little about the interventions, processes, and roles of HCSEs in facilitating public value creation (Moore, 1995), and how and where HCSEs come into the picture of being involved in health service production and delivery. Therefore, in this study, we asked an important 
question: How do healthcare social enterprises (HCSEs) contribute to public service provision in the health sector?

\section{New Public Governance and Healthcare Social enterprises}

In the past two decades or so, public sector institutions have become more reliant on interdependent relationships with the private sector and civil society actors to address public policy problems (Elliott and Salamon, 2002). New Public Management (NPM), which represented an attempt to make the public sector more business-like and to improve the efficiency of the public sector (Ferlie et al., 1996), has been criticised for its limitation and narrow focus in capturing and contributing to the management and governance of public services delivery (Osborne, 2010). Scholars argued that the intra-organisational focus of NPM could not reflect the inter-organisational and interactive nature of contemporary public services provision (Lindsay et al., 2014).

In contrast to NPM, NPG, which is rooted within organisational sociology and network theory, acknowledges the plural and pluralist worlds and the increasingly fragmented and uncertain nature of public management (Brandsen et al., 2013). NPG captures a shift in the roles and responsibilities of bureaucracies and the engagement of private agencies, civil society organisations, and citizens which, in part, is due to demands for better-quality services, the drive for efficiency and the shrink in the budgets for some public services (Osborne, 2010). NPG recognises: the broad range actors involved in service delivery, including individuals and organisations; diverse processes of service delivery; and emphasises how services are increasingly 'co-produced' in collaboration with stakeholders (Lindsay et al., 2014; Mazzei et al., 2019). 
Co-production refers to the involvement of individuals and organisations in collaborating with government agencies in both the design and management of services as well as their delivery (Howlett et al., 2017). Co-production is closely linked to the concept of value co-creation (Osborne, 2018) where value is co-created with users. A service creates value only when users interacts with the service (Osborne, 2018). Co-creation concerns service experience, not just its delivery.

In the past decade or so, third sector organisations (TSOs) have played more active roles as co-producers of a range of public services in many countries. These new forms of relationship represent alternative ways of harnessing the capacities of various partners, bringing about innovative responses to complex social issues (Brown et al., 2013) and offering a potentially sustainable solution to public problems (Hall et al., 2012). For policymakers, the involvement of TSOs in co-producing public services can ensure more specialist services shaped to the needs of users with complex issues (Teasdale and Dey, 2019) and also strengthen the 'contestability' between possible providers in social service provision markets (Brandsen et al.,2013).

In relation to healthcare social enterprises (HCSEs), existing literature suggests that social enterprises are symbolically legitimate in a predominately neoliberal era, given that these organisations employ business principles in the service of some form of 'social good' (Dart, 2004). Social enterprise is characterised as a complex entity that has the characteristics of public, private, and non-profit sectors (Brandsen and Karre, 2011; Calò et al., 2018; Defourny and Nyssens, 2010; Chandra and Paras, 2020). The complex nature of social enterprise is further enriched by the heterogeneity of its organizational forms, operating models, fields of work, the involvement of public sectors in public and social services in different country contexts. Scholars have highlighted how historical context that drives social enterprises 
emergence differs across countries and regions (Chandra et al., 2021; Defourny et al., 2020; Kerlin, 2013) which include welfare governance, civil society structure, legal and tax system as well as regimes of support for social enterprises which include the government, foundations, incubators, and umbrella organizations that support social enterprises including Ashoka.

From the perspective of NPG, social enterprises are conceptually interesting to study due to their 'hybrid' nature (Battilana and Lee, 2014), which allows them to bridge business and civil society functions, drawing on different 'institutional logics' (Battilana and Lee, 2014) and recognises their increasing role in policy arrangements and service delivery (Millar and Hall, 2013). To date, some forms of social enterprise have become active agents for public service delivery, either directly on behalf of the state, or in response to the gaps produced by the shrinking of the welfare state (Roy et al., 2014). A social enterprise approach which marries public service and business models arguably improves their organisational sustainability, as well as the quality of services delivered (Powell et al., 2019). Nevertheless, managing hybridity can be challenging. Scholars have cautioned against the negative aspects of hybridity, including the potential financial, cultural and political risks (Brandsen and Karre, 2011) and mission drifting (Ebrahim et al., 2014).

\section{An Overview of Healthcare Social Enterprises}

One reason for the growing interest in social enterprise is its involvement in the provision of health services in places where healthcare has traditionally been considered as the responsibility of government (and, indeed, in places where the third sector or private for-profit sector is the dominant mode). Prior research has widely discussed the potential of social enterprises to improve the health and well-being of individuals and communities (e.g., Roy et al., 2014; Farmer et al, 2016), broaden opportunities for social connection (Farmer, 2020), and empower disadvantaged people to make choices (i.e., Chandra and Shang, 2021). In particular, 
extant studies have uncovered that the functions of HCSEs as a socially innovative response to complex health issues are two-fold.

First, HCSEs have been regarded as an alternative mode of delivery of healthcare services in some jurisdictions, responding to gaps in mainstream service provision (Roy et al., 2013). For example, in the United Kingdom, the government has facilitated the development of social enterprises to deliver health and social care and has transferred some National Health Services (NHS) to social enterprise 'spinouts' (Hall, et al., 2012; Roy et al., 2013). NHS employees were given a 'Right to Request' to set up 'social enterprises' to deliver community health services as part of a purchaser-provider split (Miller et al., 2012; Hall et al., 2012). In these cases, social enterprises have been viewed by policymakers as a vehicle within the formal healthcare system to offer higher levels of innovation, cost-efficiency and responsiveness to societal needs (Allen, 2009). Similarly, in Italy, 'social cooperatives' have been increasingly involved in delivering medical and healthcare services as an innovative approach to reducing costs of public health expenditure (Borzaga and Fazzi, 2014). However, in so-called 'developing' and 'less developed' countries - often characterized by market and the government failure in the healthcare services - the contribution and roles of healthcare social enterprises is relatively unknown.

Secondly, social enterprises also impact the health and wellbeing of individuals and communities by addressing social determinants of health: the factors in the social environment which shape how people are born, grown, live, work and age (Solar and Irwin, 2010). Existing studies have pointed out that social enterprises also play a role at addressing the individual and daily living conditions that will eventually create, enhance and improve the physical, mental and social well-being of individuals (Roy et al., 2013; Mason et al., 2015). For example, through engaging disadvantaged people in meaningful employment, social enterprises that 
provide work-integration opportunities have been effective in improving beneficiaries' mental health, self-reliance/esteem, health behaviors, life satisfaction, and social relations (Krupa et al., 2019). Importantly, research has also found that activities delivered by social enterprises can support improvements in physical activity and decrease depressive symptoms (Calò et al., 2019).

Overall, prior research has pointed out the two (quite separate) functions of social enterprises in improving health and well-being of individuals: either directly engaging in service provision; or in addressing social determinants of health (Farmer et al., 2016; Roy et al., 2014; Calò et al., 2019). However, despite the growing interests on the contributions of HCSEs, research that has adopted an NPG perspective has largely focused on their role as direct service providers (i.e., Pestoff, 2012), while ignoring other possible contributions of social enterprise in public service management. Moreover, extant studies in the NPG context have mainly adopted a public sector perspective by investigating how governments collaborate with different actors in the design, management, and delivery of public services (i.e., Pestoff and Brandsen, 2010; Lindsay et al., 2014). Crucially, previous research has not considered the micro-level interventions of HCSEs in a sufficiently broad context, and has also insufficiently dealt with the heterogeneity of social enterprises (Macaulay et al., 2018). Different historical antecedents (Defourny et al., 2020; Kerlin, 2013) may result in different models and functions of healthcare social enterprises, however we do not seek to theorize about antecedents of country or regional differences in the work of HCSEs. Rather, we seek to explore what HCSEs do, and their contributions.

\section{Methodology}

To answer the research question, we conducted a qualitative content analysis, combining a qualitative grounded theory approach (Glaser and Strauss, 1967) with the Gioia methodology 
(Gioa et al., 2013) using open (first-order), axial (second-order), and selective (aggregate dimension) coding to analyze a sample of 172 social entrepreneurs whose organisations operate in healthcare-related sector to unpack their interventions and contributions in tackling healthcare challenges.

\section{Sampling}

Our sample came from HCSEs that have been supported by Ashoka, Schwab and Echoing Green (see Supplementary Material). These organisations are among the world's largest platforms supporting social entrepreneurs at country, regional and global levels. As such, although they could not be said to be representative of all social entrepreneurs, nor, indeed, social enterprises everywhere, they provide an excellent cross-section and a useful repository of information for systematic analysis of this kind. The HCSEs supported by Ashoka, Schwab and Echoing Green are selected using rigorous criteria (see Supplementary Material).

From this we retrieved the organizational profiles of those Fellows and focused on their interventions to address healthcare problems. The "profiles" formed the core of the data analyzed in this article. The profiles were written and maintained by the three platform organizations respectively based on interviews with social entrepreneurs and presented in unified formats on their websites. Ashoka had more than 3,000 Fellows as of November 2016 and categorised its Fellows into six fields of work - civic engagement, economic development, environment, healthcare, human rights, and learning/education. Out of these Ashoka Fellows, there were 388 (or 12.9\%) working in the healthcare field. The Schwab Foundation, by the time of data collection (November 2016), had a total of 325 Schwab Fellows in different fields of work, with 93 of them (28.6\%) working in the health sector. Echoing Green had 582 Fellows by 2016 , across various fields of work with 84 of them (or 14.4\%) working in the health sector. 
From this population of $565(388+93+84)$ HCSEs, we randomly selected 60 from each platform organisation. Using a random generator in $\mathrm{R}$ (a programming language), we randomly selected 60 out of 388 Ashoka HCSEs. We repeated the same sampling process for Schwab and Echoing Green HCSEs. Due to some data overlap (8 cases), because some social enterprises were affiliated with more than one platform (e.g., being both an Ashoka and Schwab Fellow), we ended up with 172 unique cases in the analysis, in which 60 from Ashoka, 55 from Schwab, and 57 from Echoing Green). The sample breakdown (see Supplementary Material) shows how the samples were spread across Africa, Asia, Europe, South, Central and North America.

\section{Qualitative Data Analysis}

The 172 randomly selected Ashoka, Schwab and Echoing Green intervention texts extracted from the websites were imported into computer-assisted qualitative data analysis software (CAQDAS) for analysis. Before the actual analysis, two research members coded five profiles on Ashoka HCSEs and manually read each of them to become familiar with the nature of these narratives. In the actual analysis, two research team members conducted qualitative "open coding" (Corbin and Strauss, 1990) on these intervention texts independently. The open coding process was iterative and extensive and generated 1162 first-level (and highly detailed) codes for the HCSEs interventions (e.g., used hospital halls and waiting rooms as classrooms to educate patients and their families).

Developing the coding structure in an iterative fashion, involving eight meetings over an 18-month period, we reached a consensus with regard to the topics and themes apparent from the data. We combined all first-level codes into 10 second-order categories (e.g., enhancing social and economic competence through skills development), and finally reduced them to three aggregate dimensions (e.g., improving quality of health services). In doing so, we cycled between the codes and the literature (Gioia et al., 2013) to make sense of the findings 
and to better ground them in existing research. We present our findings using "power quotes" whenever necessary to highlight salient points, increase understanding, and increase the credibility of our findings.

\section{Findings}

Our study revealed the HCSEs have worked on three different dimensions to improve the health and well-being of individuals and communities, which are: 1) improving access to health services; 2) improving quality of health services; and 3) building community health capacity. Each is discussed in turn.

\section{Improving Access to Health Services}

Firstly, improving access to health services includes strategies to improve availability, accessibility, and affordability of health services so that more people would have access to health resources. In doing so, HCSEs have interacted with a wide range of stakeholders including communities, health workers, governments and business sector and made efforts in four aspects: 1) filling the gaps in health service provision, 2) connecting patients to existing health providers, 3) strengthen healthcare workforce, and 4) lowering prices for health services. The findings suggested that the roles and functions of HCSEs are multi-dimensional and operate with diverse stakeholders at different levels (i.e. individual, community, public policy levels) in their interventions.

Filling the gaps in health service provision

The most common intervention employed by HCSEs to improve the accessibility of health services is providing health services directly outside public health systems to fill institutional voids. These gaps might be caused by shortages of healthcare professionals, inaccessible geographic areas of residence or strict working hours to see a doctor. Through delivering 
community-based health services directly to people in need, HCSEs compensate for inadequate health services provided by public institutions. Some HCSEs have developed online platforms for online health consultations (e.g., CIES by Ashoka Fellow Roberto Kiwaka, Brazil). Moreover, to address the issues of lacking availability of health services in rural areas, some HCSEs in our study provided flexible mobile clinic services for treating isolated and vulnerable groups, as noted in the profile of the Echoing Green Fellow Christopher Ategeka (Uganda), founder of Rides for Lives:

“We [Rides for Lives] manufactured locally sourced medical vehicles with the mission of improving medical access to those that are the most vulnerable... Our mobile Health unit is a refitted bus that contains three different medical stations: a pharmacy that is attended by a full-time pharmacist, a lab that has the ability to carry out different medical tests, and a medical station staffed by a full-time general health practitioner to see patients daily"

\section{Connecting patients to health providers}

Second, connecting patients to health providers operates as a form of intervention by acting as a bridge between patients and health providers. In doing this, some HCSEs have collaborated with health professionals directly by building a network that integrates health workers with different specialties, so that patients with fewer networks could find suitable doctors and seek medical advice more easily than before. One example is the Commonwealth Care Alliance (by Ashoka Fellow Robert Master, United States) that connected patients with a team of physicians and nurses to provide medical assessments, intensive medical and behavioral healthcare, and social support services in the home and community. Some HCSEs provided referral services by referring patients to health facilities to ensure that they receive the best possible care at the appropriate level. Other HCSEs recognised a lack of transportation as a key problem facing 
disadvantaged populations and provided transportation services using boats or modified bikes as ambulances to transport patients to health providers. An example of this was a ship ambulance provided by Friendship by Schwab Fellow Runa Khan (Bangladesh).

\section{Strengthening the healthcare workforce}

The HCSEs also engaged in strengthening the healthcare workforce by empowering community and local health workers, many of whom lack sufficient supervision and health training, through a series of training programs. They have employed multifaceted strategies to increase both the quantity and quality of community health workers through training, mobilisation and empowerment. For instance, some HCSEs trained villagers to become community health workers to provide primary care in their villages to reduce the burdens of public health institutions. As quoted from a Schwab Fellow, Sakena Yacoobi (Afghanistan), founder of Afghan Institute of Learning (AIL):

"Working with the Ministry of Health, AIL trained community health workers (CHWs) who are chosen by the villagers... CHWs refer villagers to the clinics, give first aid... and give health education... The CHWs program has been very successful in being a point of triage taking care of some things that do not need clinic care which relieves clinic numbers and... helps prevent illness in the first place”

\section{Lowering prices for health services}

Another HCSE intervention was to improve the affordability of health services by lowering prices for health services and products and improving health financing systems. This intervention typically comes in two forms: self-manufacturing and policy reform. For instance, some HCSEs in our study partnered with medical companies in developing and manufacturing health products and medicines and offered them at lower than market price. Others advocated 
for health policy reforms to lower healthcare costs, such as the work of Network Access to Essential Medicines by Ashoka Fellow Simon Kabore (Burkina Faso) that: "[We] built a coalition to lobby the government to provide antiretroviral drugs at zero cost, which it was receiving for free from an international donor, but selling to HIV positive citizens for 8,000 cfa (US\$16.75) per month".

In addition, we identified that some HCSEs in our study have developed pro-poor health financing schemes such as providing low-cost health insurance in partnership with insurance companies and other stakeholders to promote health coverage of poorer communities (e.g., Naya Javeen by Schwab Fellow Ansher Hasan, Pakistan).

\section{Improving the Quality of Health Services}

The HCSEs collaborated with a wide range of stakeholders such as health professionals, medical scientists, and governments to improve the quality of health service delivery. There are three major interventions to achieve this: 1) optimising treatment options through innovations, 2) strengthening the capacity of health professionals, and 3) monitoring health service performance.

Optimising treatment options through innovations

Providing more choice to existing health providers to improve the quality of their health services was also a key approach. This innovation can take place at different levels: the health product or service, the process of service delivery, and health system management method. For instance, some HCSEs focused on developing new disease detection and prevention systems such as the work of Alois (by Ashoka Fellow Bénédicte Défontaines, France) that offered integrated services of early detection, psychological support, risk prevention, medical care, and palliative care for patients. Other examples include utilising information communication 
technology and other advanced technologies to improve healthcare management systems particularly in organising patient-related medical or healthcare data in health institutions. For example, Koe Koe, Echoing Green Fellow Michael Lwin (Myanmar), developed a health information system for various Myanmar hospitals to track patients, and mobile apps for doctors to access patient's information.

Strengthening the capacity of health professionals

We also found that the HCSEs developed close collaborations with health institutions and medical schools to empower in-service and future health personnel through education and training. For example, CISEPO, by Ashoka Fellow Arnold Noyek (Canada), combined education/training, research and service for medical students and professionals and whose curriculum have been used by 30 medical institutions. Moreover, some HCSEs have developed online platforms that integrate health professionals with different specialties at different levels and different geographical locations to facilitate knowledge exchange. For example, BE MORE, by Echoing Green Fellow Anurag Gupta (United States), developed an online training program to encourage the use of evidence-based medicine and improve physician-patient trust and communication.

\section{Monitoring the performance of health services}

HCSEs also acted as a third-party evaluator to monitor the performance and effectiveness of public health services. We found that some HCSEs have developed new protocols and standards for healthcare services to ensure that health services could be delivered effectively. The HCSEs also mobilised community volunteers as the watchdog in holding health providers accountable by verifying and monitoring medical treatment and care services at health institutions. This is well illustrated in Karuna Trust, by Schwab Fellow Sudarshan Hanumappa (India): 
"Through the village council, the community is an active stakeholder participating in the planning and monitoring of the PHC's functioning instead of being a passive recipient of inadequate services... Village councils hold their PHCs accountable for achieving better health outcomes and functioning as zero-corruption zones".

\section{Building Community Health Capacity}

The last type of function performed by HCSEs we identified was in relation to building community health capacity. In doing so, the HCSEs employed three major interventions: 1) improving public health knowledge and behaviors; 2) enhancing social and economic competence; and 3) strengthening community care and self-care capacity.

Improving public health knowledge and behaviors

The HCSEs emphasised improving public health knowledge and promoting good health behaviors at both individual and community levels through collaborations with different stakeholders. For instance, some HCSEs partnered with schools and governments to deliver public education on health and hygiene. They adopted various media to disseminating health information through different media channels (e.g., documentation, social media platforms). For example, Félúton Alapítvány, by Schwab Fellow Csaba Kovács (Hungary), conducted partnerships with schools and businesses, and launched programs educating young people to address alcohol addiction. Other HCSEs employed behavioral incentives to stimulate change that enables low-income customers to purchase affordable fresh food (e.g., Wholesome Wave, by Ashoka Fellow Michel Nischan, United States).

Enhancing the social and economic competence of the public

The HCSEs implemented multiple interventions to provide skills, knowledge, and competencies that people require to become more independent and take greater control of their 
lives. This is a form of empowerment approach that has been used by many social enterprises. We identified that some of these interventions have focused more on social aspects, such as providing free legal services to vulnerable communities, fulfilling their basic needs by providing shelter and food or facilitating social connections within communities. For example: Heartlines, developed by Schwab Fellow Garth Japhet (South Africa), uses a mobile-phonebased social networking tool called "Forgood" to connect people based on similarity in location and interests to enhance social connectedness. Other HCSEs focused more on economic empowerment approaches to support community members via vocational training, employment opportunities, and financial support. One example is the work of Community Enterprise Solutions by Ashoka Fellow Gregory Van Kirk (Guatemala), as follows:

"[The] model creates access to healthcare-related goods and services in isolated rural communities [by empowering] local women to become entrepreneurs to sell [healthcare-related] goods and services in their communities... It gives individuals with no prior business experience the opportunity to develop entrepreneurial skills"

Strengthening community care and self-care capacity

Finally, the HCSEs implemented interventions to enable community members to provide care for themselves, their families and neighbors through a series of health skills training programs, which allows more efficient use of available human resources and quicker responses to community members' needs for healthcare and reduces burdens of public health providers. This is well illustrated in the work of Noora Health, by Echoing Green Fellow Katy Ashe (United States):

"[The HCSE] delivers health skills training to at-risk patient families - certifying them in everything from hygiene to recognition of early warning signs. They meet users where they are by turning hospital hallways, waiting rooms and wards into classrooms. 
By certifying families in the conditions they face, they give community members the ability to heal and prevent disease when they return home".

\section{Theorizing Healthcare Social Enterprises in the Public Health Context}

To 'reach closure' in the qualitative analysis, we cycled back and forth between the findings (Gioia et al., 2013) and the public health literature, particularly the social enterprise and NPG literature, and identified eight major activities and contributions that HCSEs played in healthcare services (see Table 1), which are: 1) policy implementer, 2) service coordinator, 3) industry watchdog or regulator, 4) performance monitor, 5) lead service providers, 6) service or process innovator, 7) policy lobbyist, and 8) institutional integrator. To provide a framework to summarise the findings, we juxtaposed our typology of HCSEs with three modes of co-production (i.e., co-production, co-management, and co-governance, following Brandsen and Pestoff, 2006; and co-planning, co-design, co-prioritisation, co-financing, co-managing, co-delivery, and co-assessment, following Bovaird and Loeffler, 2012) as a lens to understand how HCSEs are drawn into health service provision and to characterise their roles in the NPG framework.

Our findings reveal that HCSEs have the capabilities and promise in engaging in various types of co-production in healthcare services that converge with and add new dimensions to those known in the NPG literature (see Table 1).

Insert Table 1 about here

As shown in Table 1, HCSEs can act as policy implementer. This role is consistent with the co-management and co-delivery mode of NPG in which HCSEs help implement government policies to deliver health and social services directly to citizens through contractual relationships. This reflects the public-private partnerships (PPPs) model employed by social 
enterprises to provide public goods and services by utilising their specific expertise and skills (Nisar et al., 2013).

Second, HCSEs also play the role as service coordinators to match unmet needs or unused resources or poorly connected resources. This aligns well with the co-management mode of NPG. Examples include providing transportation services to connect patients in rural areas to existing health providers, which enables more efficient use of existing health resources. This shows that in the co-management process, the HCSEs can harness the productive capability civil society and government sectors to resolve complex health problems (Brown et al., 2013).

Third, HCSEs play a critical role as industry regulators such as by taking active part in regulating the service standards in the health sector as well as influencing policy formulation and community governance at the local and national levels. Fourth, they also act as performance monitors that evaluate and monitor the service performance and accountability of public service provision, working to enhance the co-governance and co-assessment mode of NPG.

The subsequent findings below reflect some new types of contributions for HCSEs that offer new contribution beyond the typology of co-production (Brandsen and Pestoff, 2006; Bovaird and Loeffler, 2012) that we found in this study. That is, fifth, HCSEs can act as lead service providers to fill institutional voids through using their own hobbies and expertise to develop pioneering services not yet available in the market, such as using mobile clinics to provide healthcare services to patients in rural areas and developing e-platforms to provide online medical consultations. Sixth, HCSEs also act as service or process innovators by developing new services and products for healthcare provision. Examples include developing innovative infant incubators to protect vulnerable new-borns from hypothermia or designing 
more effective and sustainable mobility aids and appliances to support people with disabilities. We identify these roles as the co-innovation mode of NPG, in which HCSEs introduce innovative practices into health service provision and delivery (see Farmer et al., 2020).

Seventh, HCSEs also play a role as policy lobbyist. HCSEs can influence the policy formulation and improve policy processes and outcomes by ensuring that policies are implemented and informed by local context and relevant to local needs, and at times using local wisdom. For example, HCSEs have lobbied the government to offer life-extending medications to the public and especially to the poor communities at lower prices. We call this role the $c o$ design mode of NPG. Lastly, HCSEs can serve as institutional integrators by mobilising and coordinating public health improvement activities and bridges the interests of the government, academic, private sector and the community with new governance structures that encourage broad participation in public health issues. By doing so, different sectors and organisations become increasingly interdependent and resilient in adapting to continuous changes needed to improve health services. We call this role the co-integrator mode of NPG.

Overall, the findings reveal new empirical evidence on the distinctiveness, richness, heterogeneity of HCSEs beyond a specific setting in addressing health problems.

\section{Discussion and Conclusion}

To answer the question 'How do healthcare social enterprises (HCSEs) contribute to public service provision in the health sector?', we conducted a study of 172 HCSEs from three major platform organizations. As we have shown, HCSEs employ multifaceted interventions, collaborating with different stakeholders including community, health workers, health institutions, governments, and the business sector. Importantly, our findings have demonstrated that social enterprises not only diversify public service provision - as co-producers within the 
NPG framework - but also have the potential to take on a wide range of roles (such as coordinating health service provision or advocating for health policy reforms) in achieving the ultimate goal of improving health for all, as shown in Figure 1.

\section{Insert Figure 1 about here}

As we stated at the outset, there has been increasing interest in the role of civil society organisations in the provision of health services (e.g., Roy et al., 2013). Building on the conceptualisation of social enterprises as an instrument to improve the health and wellbeing of individuals and communities (viz. Roy et al., 2014), we have examined the interventions of, and roles played, by 172 unique HCSEs (i.e., whose work primarily focus on the healthcare sector) across Africa, Asia, Europe, South, Central and North America that were developed as part of Ashoka, Echoing Green and Schwab fellowships. Our study reveals that social entrepreneurs could play different roles and use different interventions across different contexts of health systems. By adopting a qualitative content analytical approach using grounded theory to analyze the intervention profiles of the HCSEs, we have identified that HCSEs interventions can be categorised into three dimensions: improving access to health services; improving the quality of health services; and building public health capacity. We also found eight major roles that HCSEs play in the provision of health services that are consistent with, and offer new dimensions, beyond a narrow reading of the concept of co-production; namely: policy implementer, service coordinator, industry watchdog or regulator, performance monitor, lead service providers, service or process innovator, policy lobbyist, and institutional integrator.

Our contributions are thus twofold. Firstly, this article contributes to an enhanced understanding of the micro-level interventions of social enterprises that focus on solving complex health problems. This extends and advances prior research, which has tended to focus on the organisational or institutional aspects of social enterprises in the healthcare setting, or 
on the indirect outcomes of the actions of social enterprises on health and wellbeing (e.g., Hall et al., 2015; Hall et al., 2012; Mason et al., 2015; Roy et al., 2017). We have shown that interventions by HCSEs (see Figure 1) are rich, diverse, yet also multi-level and multidimensional (e.g., connecting patients to health providers, strengthening community care and self-care capacity, optimising treatment options through innovations) to produce health services and influence the process and outcomes of health service provision. Therefore, this article deepens our understanding of the nature, process and, to some limited extent, the outcomes of HCSE interventions.

Secondly, using an NPG perspective as an initial framework to explore the interventions and roles of HCSEs, this article is the first to show that HCSEs are important coproducers of public health services (c.f. Howlett et al., 2017). We identified eight major roles that HCSEs play in the health services provision and delivery: policy implementer, lead service provider, service coordinator, servicel process innovator, industry regulator, performance monitor, policy lobbyist, and institutional integrator. We also showed how they corresponded with the concepts of co-management, co-delivery, co-governance and co-assessment (viz. Brandsen and Pestoff, 2006; Bovaird and Loeffler, 2012). Importantly, our new contribution comprises the identification of the roles of co-innovation, co-lobbying, and co-integrator as new dimensions of NPG framework by situating it in the context of healthcare.

Overall, the key contributions of this study have been to unpack the heterogeneity of the interventions of and roles played by HCSEs in addressing health problems as a means to create public value (Moore, 1995) and providing theoretical and practical insights into how the concept of NPG can be applied to the healthcare setting. These findings could enable social enterprise and public health/management scholars to define and/or expand upon the forms of collaboration, funding, piloting, scaling, and competition that the public sector could establish 
with citizens and civil society organisations, particularly given the growing complexity of health problems and pressing global health challenges. For example, there is a growing trend of citizen innovators and social enterprises developing translation apps, creating face shields or other medical devices during the COVID-19 pandemic in the West and the East. This study offers new insights into how governments and businesses can work with citizens and civil society to improve health services.

Our study does, however, have several limitations. Firstly, the sample of HCSEs in this study was drawn from Ashoka, Echoing Green and Schwab platform organisations, which are not representative of social enterprises generally, particularly bottom-up, grassroots action initiated by citizens. Each of the platforms we focused upon employs strict criteria in the selection process of who they support: they seem to have selected especially prominent or impactful healthcare social enterprises. Future research could expand the study by examining social enterprises not connected to these foundations in specific regional contexts, particularly in terms of differences in interventions, collaborations and outcomes in the health service provision.

Moreover, which HCSEs interventions produce what health and social outcomes remain understudied. Future research could look into the effectiveness and efficiency of HCSEs interventions in comparison with those provided by other sectors (e.g., government, private, non-profit) and which of the eight types of HCSE roles produce better outcomes for specific regions or health problems. This opens us new avenues to conduct randomized controlled trials, quasi-experimental methods, and laboratory and field experiments to investigate which interventions produce better outcomes in comparison to a control or 'usual' treatment. 


\section{Acknowledgments}

The authors would like to thank the organisers and attendees of the International Social Innovation Research 2020 (ISIRC) Conference, which was held on 1 - 3 September 2020, at the University of Sheffield, United Kingdom, who awarded an early draft of this article the conference's Best Paper Award.

Ethical clearance was obtained from the Hong Kong Polytechnic University (HSEARS20210120002). 


\section{References}

Barraket, J. and Yousefpour, N. (2013). 'Evaluation and social impact measurement amongst small to medium social enterprises: Process, purpose and value'. Australian Journal of Public Administration, 72:4, 447-458.

Battilana, J. and Lee, M. (2014). 'Advancing research on hybrid organizing-Insights from the study of social enterprises'. The Academy of Management Annals, 8:1, 397-441.

Brandsen, T., Pestoff, V. and Verschuere, B. (2013). Co-production as a maturing concept. In Pestoff, V., Brandsen, T., \& Verschuere, B (Eds.), New Public Governance, the Third Sector, and Co-Production (pp. 19-28). New York: Routledge.

Brandsen, T., \& Karré, P. M. (2011). Hybrid organizations: No cause for concern?. International Journal of Public Administration, 34(13), 827-836.

Brown, K., Keast, R. and Waterhouse, J. (2013). 'Co-management to solve homelessness: Wicked solutions for wicked problems'. In J. Barraket, R. Keast and C. Furneaux (eds.), New Public Governance, the Third Sector, and Co-Production (pp. 229-244). Routledge.

Calò, F., Roy, M. J., Donaldson, C., Teasdale, S. and Baglioni, S. (2019). 'Exploring the contribution of social enterprise to health and social care: A realist evaluation'. Social Science and Medicine, 222, 154-161.

Calò, F., Teasdale, S., Donaldson, C., Roy, M. J. and Baglioni, S. (2018). 'Collaborator or competitor: assessing the evidence supporting the role of social enterprise in health and social care'. Public Management Review, 20:12, 1790-1814.

Chandra, Y., Teasdale, S., \& Tjiptono, F. (2021). Social entrepreneurship research in the Greater China Region: A scoping review and new research framework. Journal of Asian Public Policy (early print version).

Chandra, Y. and Shang, L. (2021). 'Social entrepreneurship interventions in the HIV/AIDS sector: A social entrepreneurship-social work perspective'. International Social Work, 64(1), 5-23.

Chandra, Y. and Paras, A. (2020). 'Social Entrepreneurship in the Context of Disaster Recovery: Organizing for Public Value Creation'. Public Management Review (in press).

Corbin, J. M., and Strauss, A. (1990). 'Grounded theory research: Procedures, canons, and evaluative criteria'. Qualitative Sociology, 13:1, 3-21.

Craig, P., Dieppe, P., Macintyre, S., Michie, S., Nazareth, I. and Petticrew, M. (2008). 'Developing and evaluating complex interventions: the new Medical Research Council guidance'. British Medical Journal, 337:7676, 979-983.

Dart, R. (2004). 'The legitimacy of social enterprise'. Nonprofit Management and Leadership, 14:4, 411-424. 
Defourny, J., Nyssens, M., \& Brolis, O. (2020). Testing social enterprise models across the world: Evidence from the "International Comparative Social Enterprise Models (ICSEM) project". Nonprofit and Voluntary Sector Quarterly, 0899764020959470.

Defourny, J. and Nyssens, M. (2010). 'Social enterprise in Europe: At the crossroads of market, public policies and third sector'. Policy and Society, 29:3, 231-242.

Ebrahim, A., Battilana, J., \& Mair, J. (2014). The governance of social enterprises: Mission drift and accountability challenges in hybrid organizations. Research in Organizational Behavior, 34, 81-100.

Eikenberry, A. M., \& Kluver, J. D. (2004). The marketization of the nonprofit sector: Civil society at risk? Public Administration Review, 64(2), 132-140.

Elliott, O. V. and Salamon, L. M. (2002). The Tools of Government: A Guide to the New Governance. Oxford University Press.

Farmer, J., De Cotta, T., McKinnon, K., Barraket, J., Munoz, S. A., Douglas, H. and Roy, M. J. (2016). 'Social enterprise and wellbeing in community life'. Social Enterprise Journal, 12:2, 235-254.

Farmer, J., Kamstra, P., Brennan-Horley, C., De Cotta, T., Roy, M., Barraket, J. ... and Kilpatrick, S. (2020). 'Using micro-geography to understand the realisation of wellbeing: A qualitative GIS study of three social enterprises'. Health and Place, 102293.

Ferguson, K. M. (2012). 'Merging the fields of mental health and social enterprise: Lessons from abroad and cumulative findings from research with homeless youths'. Community Mental Health Journal, 48:4, 490-502.

Ferlie, E., Fitzgerald, L. and Pettigrew, A. (1996). The New Public Management in Action. OUP Oxford.

Ganz, M., Kay, T., \& Spicer, J. (2018). Social enterprise is not social change. Stanford Social Innovation Review, 16(Spring), 59-60.

Gioia, D. A., Corley, K. G. and Hamilton, A. L. (2013). 'Seeking qualitative rigor in inductive research: Notes on the Gioia methodology'. Organizational Research Methods, 16:1, 15-31.

Glaser, B. and Strauss, A. (1967). The discovery of grounded theory. London: Weidenfield and Nicolson

Gray, M., Healy, K., \& Crofts, P. (2003). Social enterprise: Is it the business of social work? Australian Social Work, 56(2), 141-154.

Hall, K., Alcock, P. and Millar, R. (2012). 'Start up and sustainability: Marketisation and the social enterprise investment fund in England'. Journal of Social Policy, 41:4, 733-749.

Hall, K., Miller, R. and Millar, R. (2012). 'Jumped or pushed: what motivates NHS staff to set up a social enterprise?'. Social Enterprise Journal, 8:1, 49-62. 
Hoogendoorn, B., Pennings, E., \& Thurik, R. (2012). Conceptual overview of what we know about social entrepreneurship. In DeFilippis, J., \& Saegert, S. (Eds.), The Community Development Reader, $2^{\text {nd }}$ Ed, New York: Routledge, p. 117-124.

Howlett, M., Kekez, A. and Poocharoen, O. O. (2017). 'Understanding co-production as a policy tool: Integrating new public governance and comparative policy theory'. Journal of Comparative Policy Analysis: Research and Practice, 19:5, 487-501.

Jenson, J. (2017). 'Modernising the European social paradigm: Social investments and social entrepreneurs'. Journal of Social Policy, 46:1, 31-47.

Kerlin, J.A. (2013). Defining social enterprise across different contexts:_A conceptual framework based on institutional factors. Nonprofit and Voluntary Sector Quarterly, 42(2), 84-108.

Krupa, T., Sabetti, J. and Lysaght, R. (2019). 'How Work Integration Social Enterprises Impact the Stigma of Mental Illness'. Social Enterprise Journal, 15:4, 475-494.

Lindsay, C., Osborne, S. P. and Bond, S. U. E. (2014). 'The 'new public governance' and employability services in an era of crisis: Challenges for third sector organizations in Scotland'. Public Administration, 92:1, 192-207.

Macaulay, B., Mazzei, M., Roy, M. J., Teasdale, S. and Donaldson, C. (2018). 'Differentiating the effect of social enterprise activities on health'. Social Science and Medicine, 200, 211-217.

Mason, C., Barraket, J., Friel, S., O'Rourke, K., \& Stenta, C. P. (2015). Social innovation for the promotion of health equity. Health Promotion International, 30(suppl_2), ii116-ii125.

Mazzei, M., Teasdale, S., Calò, F. and Roy, M. J. (2019). 'Co-production and the third sector: conceptualising different approaches to service user involvement'. Public Management Review, 1-19.

Mendell, M. (2010). 'Reflections on the evolving landscape of social enterprise in North America'. Policy and Society, 29:3, 243-256.

Millar, R. and Hall, K. (2013). 'Social return on investment (SROI) and performance measurement: The opportunities and barriers for social enterprises in health and social care'. Public Management Review, 15:6, 923-941.

Miller, R., Millar, R. and Hall, K. (2012). 'New development: Spin-outs and social enterprise: the 'right to request' programme for health and social care services'. Public Money and Management, 32:3, 233-236.

Moore, M. H. (1995). Creating Public Value: Strategic Management in Government. Harvard University Press.

Nisar, T. M. (2013). 'Implementation constraints in social enterprise and community public private partnerships'. International Journal of Project Management, 31:4, 638-651.

Osborne, S. P. (2010). Public governance and public services delivery: a research agenda for the future. In The New Public Governance, (pp. 413-428). Routledge. 
Osborne, S. P. (2018). From public service-dominant logic to public service logic: are public service organizations capable of co-production and value co-creation? Public Management Review, 20:2, 225-231.

Pestoff, V. (2012). 'Co-production and third sector social services in Europe: Some concepts and evidence'. Voluntas: International Journal of Voluntary and Nonprofit Organizations, 23:4, 1102-1118.

Pestoff, V. and Brandsen, T. (2010). Public governance and the third sector: opportunities for co-production and innovation?. In Osborne, SP (ed.), The New Public Governance: Emerging Perspectives on the Theory and Practice of Public Governance, 223-236. Routledge

Powell, M., Gillett, A. and Doherty, B. (2019). 'Sustainability in social enterprise: hybrid organizing in public services'. Public Management Review, 21:2, 159-186.

Roy, M. J., Donaldson, C., Baker, R. and Kay, A. (2013). 'Social enterprise: new pathways to health and well-being?'. Journal of Public Health Policy, 34:1, 55-68.

Roy, M. J., Donaldson, C., Baker, R. and Kerr, S. (2014). 'The potential of social enterprise to enhance health and well-being: A model and systematic review'. Social Science and Medicine, 123, 182-193.

Roy, M. J., Macaulay, B., Donaldson, C., Teasdale, S., Baker, R., Kerr, S. ... and Teasdale, S. (2018). 'Two false positives do not make a right: Setting the bar of social enterprise research even higher through avoiding the straw man fallacy'. Social Science and Medicine, 217, 42-44.

Solar, O. and Irwin, A. (2010). A Conceptual Framework for Action on the Social Determinants of Health. World Health Organisation. Retrieved on 15 June 2020 from http://whqlibdoc.who.int/publications/2010/9789241500852_eng.pdf

Teasdale, S. and Dey, P. (2019). 'Neoliberal governing through social enterprise: Exploring the neglected roles of deviance and ignorance in public value creation'. Public Administration, 97:2, 325-338.

Venot, J. P. (2016). A success of some sort: Social enterprises and drip irrigation in the developing world. World Development, 79, 69-81. 
Table 1. Theorizing Social Enterprise Contribution in Healthcare Services

\begin{tabular}{|c|c|c|c|}
\hline SE Contributions & $\begin{array}{c}\text { Linkage to Brandsen \& } \\
\text { Pestoff (2006) or Bovaird \& } \\
\text { Loeffler (2012) NPG typology }\end{array}$ & Characteristics of SE Roles & Sample Quotes from SE Profiles \\
\hline Policy Implementer & Co-management, Co-delivery & $\begin{array}{l}\text { Providing public services as alternative service } \\
\text { providers through contractual relationships with public } \\
\text { sectors }\end{array}$ & $\begin{array}{l}\text { By providing medical care and training, the Alliance for } \\
\text { Rehabilitation works to integrate disabled adults into } \\
\text { Hungarian society. Its operations are primarily financed } \\
\text { through government aid based on long-term contracts with }\end{array}$ \\
\hline Service Coordinator & Co-management, Co-managing & $\begin{array}{l}\text { Coordinating the process of service delivery by } \\
\text { matching patients with appropriate health services } \\
\text { and providers }\end{array}$ & $\begin{array}{l}\text { Maniapure arranges all transport and appointments for } \\
\text { patients require transport to Caracas or other major cities } \\
\text { for in-person treatment, minimizing the time patients are } \\
\text { away from home and the time commitment of the specialists }\end{array}$ \\
\hline Indus try Regulator & Co-governance & $\begin{array}{l}\text { Setting performance standards or protocols to } \\
\text { regulate performance of health care services }\end{array}$ & $\begin{array}{l}\text { Carlos Vargas Garcia has developed new protocols for } \\
\text { prenatal care which transfer responsibility from doctors to } \\
\text { other specially trained health care professionals }\end{array}$ \\
\hline Performance Monitor & Co-governance, Co-assessment & Monitoring health service performance and quality & $\begin{array}{l}\text { To create and spread community watchdog groups, } R A M E \\
\text { partners with local citizen organizations }(C O) \text { in each } \\
\text { region that monitor quality and aggregate complaints... } \\
\text { Simon is initiating and mobilizing community health } \\
\text { watchdog committees to verify that patient treatment and }\end{array}$ \\
\hline Lead Service Provider & Co-innovation (new) & $\begin{array}{l}\text { Delivering public services as key providers through } \\
\text { innovations to fill the institutional voids }\end{array}$ & $\begin{array}{l}H T T \text { [name of the } S E \text { ] also has an outreach program } \\
\text { through mobile clinics to ensure that workers even from } \\
\text { distant farms and game reserves are accessing the services }\end{array}$ \\
\hline $\begin{array}{l}\text { Service/ Process } \\
\text { Innovator }\end{array}$ & Co-innovation (new) & $\begin{array}{l}\text { Introducing new changes to health services, products } \\
\text { or the process of service delivery }\end{array}$ & $\begin{array}{l}\text { By developing innovative evidence-based algorithms for } \\
\text { diagnosis and disease management, and by creating a } \\
\text { chain of low-cost diabetes clinics, Clinicas del Azucar is } \\
\text { revolutionizing the way diabetes care is delivered in } \\
\text { developing countries and for the fourteen million patients }\end{array}$ \\
\hline Policy Lobbyist & Co-lobbying (new) & $\begin{array}{l}\text { Advocating for changes in health systems; influencing } \\
\text { health policy formulation through co-designing the } \\
\text { policy systems }\end{array}$ & $\begin{array}{l}\text { To ensure the mental health service is widely spread, Bagus } \\
\text { is participating in the policy advocacy work for the new } \\
\text { Mental Health Act, by which he hopes that the upcoming } \\
\text { National Health Insurance will provide options to the } \\
\text { current severe side effect generic drugs. }\end{array}$ \\
\hline Institutional Integrator & Co-integrator (new) & $\begin{array}{l}\text { Developing new institutional structures by mobilizing } \\
\text { and coordinating public health improvement activities } \\
\text { across different sectors }\end{array}$ & $\begin{array}{l}\text { In Venezuela, the traditional medical system has collapsed } \\
\text { and has been replaced by a faltering state system, Martín } \\
\text { ignites a transformation in Venezuelan healthcare policy at } \\
\text { municipal, state and national levels... Rather than building } \\
\text { a parallel system, Martín acts as a catalyst to integrate } \\
\text { schools, the optometry profession, public sector agencies, } \\
\text { and the public behind his initiative. }\end{array}$ \\
\hline
\end{tabular}


Figure 1. Analytical Coding Process for Social Enterprise Interventions in the

\section{Healthcare Services Provision}

Sample First-level Codes

SE Intervention

SE Intermediate Outcomes

Long-term Impacts

- Developed an online platform to provide medical consultation services
Used mobile medical bus to provide health services in rural village

- Provided motorcycles to outreach health workers

- Referred patients to experienced doctors

Filling the gaps in health service provision

Connecting patients to health providers

- Gave speech in medical schools to foster the growth of - Recruited villagers to become community health workers

Provided fixed-cost membership for patients with diabetes care - Adrocated for lower medicine price through policy reforms

Improving access to health

\section{$\longrightarrow$ Strengthening health care workforce}

Improve affordability of health services

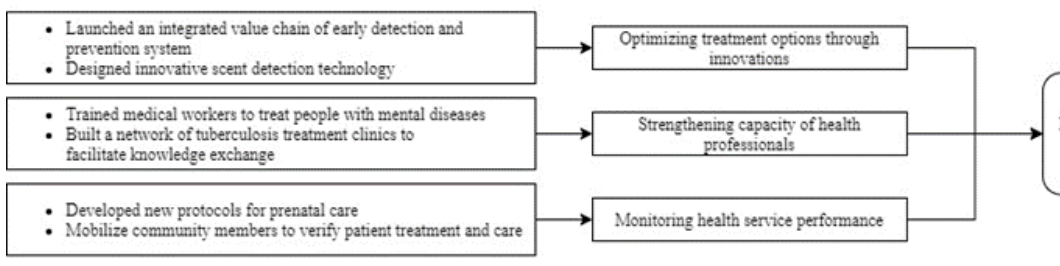

Improring quality of health

- Organized campaigns to encourage women to address health issues

Used social marketing to promote condoms to at-risk communities

Improving public health knowledge and

- Provided income generating skills training to villagers

Provided free legal support to tulnerable communities $\longrightarrow \begin{gathered}\text { Enhancing social and economic competence } \\ \text { of the public }\end{gathered}$

- Trained local women to provide reproductive health education

rengthening community case

- Trained patients' families to provide home-based care 


\section{SUPPLEMENTARY MATERIAL}

\section{Unit of analysis and definitions}

There is a lack of clarity of the linkages and differences between the concept of social entrepreneurship, social enterprise, and social entrepreneur. In this article, we broadly define 'social entrepreneurship' as entrepreneurial activities, processes, orientations, and values that aim to create social value. We define 'social enterprise' as an organizational form in which social entrepreneurship activities are actualized, implemented and formalized. Certainly, social entrepreneurial activities can occur outside of the boundary of a formal organization. We define 'social entrepreneur' as the person who initiates and participates in social entrepreneurial activities. There are various typologies that classify different definitions and dimensions of social enterprises/social entrepreneurship such as those by Hoogendoorn et al (2012), Kerlin (2006, 2012), Defourny and Nyssens (2010), and Teasdale and Dey (2019), and Chandra and Paras (2020) but despite the differences in the definitions (e.g., American Tradition vs. European Tradition vs UK tradition or Asian Tradition) there is a commonality that characterize 'social entrepreneurship/enterprise' as a hybrid organization or organizing. That is, a process of combining multiple logics, goals and approaches.

\section{The Selection Criteria for Ashoka, Schwab and Echoing Green Social Enterprises}

The three social enterprise support organizations - Ashoka, Schwab and Echoing Green - use different approaches in selecting its social entrepreneurs. Ashoka uses 5-step selection process, from nomination, first and second opinion, panel interviews, to board review; and 5 criteria (newness of idea, creativity, entrepreneurial quality, social impact, and ethical fiber) (https://www.ashoka.org/en/recommend-ashoka-fellow). 
Schwab uses referral and nomination from a global network of experts and partners and rely on several criteria including (market/tech/social) impact, potential to scale, ability to interact with top business and political leaders (https://www.schwabfound.org/selection-process).

Echoing Green uses unsolicited application approach with expert reviewers and interviews and 4 criteria which are innovation, importance of solutions, potential for impact, and a good business model (https://echoinggreen.org/fellowship/apply/).

\section{Procedures to Include only Unique Cases}

We first created a full list of all healthcare social enterprises from Ashoka in a spreadsheet and then used a random generator in $\mathrm{R}$ (a programming language) to generate random numbers to randomly select social enterprises. For example, we set $\mathrm{R}$ to give us a random of 5 samples out of a total 10 cases in the spreadsheet. And the result is 3, 4, 8, 9, and 2. Then, we select social enterprise number 2, 3, 4, 8 and 9 and retrieve their text file and conduct the coding.

In our sampling process, we found 5 fellows who were both Schwab and Ashoka Fellows, 1 fellow who was both Echoing Green and Ashoka Fellows, and 2 fellows who were both Echoing Green and Schwab Fellows (total of 8 fellows). After adjusting the samples to avoid duplication, we ended up with a total of 172 unique cases in this study.

\section{Analytical strategy}

Our analysis was not meant to show the differences among the social enterprises across regions (e.g., Asia vs. North America vs. Europe) nor to study the "trends" of the activities of social enterprises in a particular period versus other periods as this is not relevant to our research question. Rather, we are interested in how the social enterprises contribute to healthcare 
services provision generally and what we can learn from their activities to enrich and connect them with the New Public Governance literature.

\section{Distribution of Samples Included in the Study}

$\underline{\text { Year of Election }}$

Panel A: Ashoka Fellows $(n=60)$

$\begin{array}{lcc}5 & 10 & 6 \\ 3 & 3 & 1\end{array}$

$\begin{array}{lll}3 & 3 & 1 \\ 0 & 1 & 0\end{array}$

6
0
1

40

Panel B: Schwab Foundation Fellows $(n=55)$

$2010-2016$

$2000-2009$

4

Panel C: Echoing Green Fellows $(n=57)$

$\begin{array}{lll}4 & 6 & 0 \\ 1 & 0 & 0 \\ 0 & 2 & 0\end{array}$

0
0
0

0
0
0

$\begin{array}{ll}11 & 21 \\ 15 & 16 \\ 18 & 20\end{array}$

Detailed Break Down of Each Healthcare Social Enterprises in the Study 


\begin{tabular}{|c|c|c|c|c|c|}
\hline Fellow Name & $\begin{array}{l}\text { Year of } \\
\text { Election }\end{array}$ & Location & Organization & Focus of Work & Profile Weblink \\
\hline \multicolumn{6}{|l|}{ Echoing Green } \\
\hline Anurag Gupta & 2016 & North America & BE MORE America & $\begin{array}{l}\text { Physician-patient Trust \& } \\
\text { Communication }\end{array}$ & https//fellows.echoinggreen.org/fellow/anurag-gupta/ \\
\hline $\begin{array}{l}\text { Nana Amma Twum- } \\
\text { Danso }\end{array}$ & 2016 & Africa & MAZA & Pregnancy \& Ambulance Services & https://fellows.echoinggreen.org/fellow/nana-amma-twum-danso \\
\hline Katy Ashe & 2015 & North America & Noora Health & Patients' Family Empowerment & https:/fellows.echoinggreen.org/fellow/katy-ashe/ \\
\hline Sam Pressler & 2015 & North America & Armed Services Arts Partnership & Veterans Wellness & https://fellows.echoinggreen .org/fellow/sam-pressler/ \\
\hline Brittany Dejean & 2014 & North America & AbleThrive & Disability Wellness & https//fellows.echoinggreen.org/fellow/brittany-dejean/ \\
\hline Ratul Narain & 2014 & Asia & Bempu & Hypothermia & https://fellows.echoinggreen. org/fellow/ratul-narain/ \\
\hline Sumit Dagar & 2014 & Asia & Kriyate & Visually Impaired & https://fellows.echoinggreen.org/fellow/sumit-dagar/ \\
\hline Yohans Wodaje Emiru & 2014 & Africa & Telemed Medical Services & $\begin{array}{l}\text { Chromic Disease \& General } \\
\text { Healthcare }\end{array}$ & hittps//fellows.echoinggreen org/fellow/yohans-wodaje-eminu/ \\
\hline Anoop Jain & 2013 & Asia & Sanitation and Health Rights in India & Community Hygiene \& Wellness & https:/fellows.echoinggreen.org/fellow/anoop-jain/ \\
\hline Christopher Ategeka & 2013 & North America & Rides for Lives & General Healthcare & https//fellows.echoinggreen.org/fellow/christopher-ategeka/ \\
\hline Jason Panda & 2013 & North America & B Holding Group, LLC / b condoms & HIV/AIDS & https://fellows.echoinggreen.org/fellow/jason-panda/ \\
\hline T. Morgan Dixon & 2013 & North America & GirlTrek & Black Women Wellness & https://fellows.echoinggreen.org/fellow/morgan-dixon/ \\
\hline Vineet Singal & 2013 & North America & CareMessage & Hospital Efficiency & https//fellows echoinggreen. org/fellow/vineet-singal/ \\
\hline Piyush Tewari & 2012 & Asia & SaveLIFE Foundation & First Aid & https:/fellows. echoinggreen.org/fellow/piyush-tewari/ \\
\hline Touré McCluskey & 2012 & North America & OkCopay, Inc & General Healthcare & https://fellows.echoinggreen.org/fellow/toure-mccluskey/ \\
\hline Zubaida Bai & 2012 & North America & AYZH Health and Livelihood PVT & Newborn care & https://fellows.echoinggreen.org/fellow/zubaida-bai/ \\
\hline Javier Lozano & 2011 & North America & Clinicas del Azucar & Diabetes & https:/fellows.echoinggreen org/fellow/javier-lozano/ \\
\hline Mohamed Ali Niang & 2011 & Africa & Malo & Farmers Wellness & https $/ /$ fellows.echoinggreen.org/fellow/mohamed-ali-niang/ \\
\hline Peter Luckow & 2011 & North America & $\begin{array}{l}\text { Last Mile Health (known in Liberia as } \\
\text { Tiyatien Health) }\end{array}$ & General Healthcare \& HIV & https//fellows.echoinggreen. org/fellow/peter-luckow/ \\
\hline Aman Midha & 2010 & Asia & Biosense Technologies Private Limited & Diabetes Urine \& Anemia & https//fellows.echoinggreen.org/fellow/aman-midha/ \\
\hline Deepa Gangwani & 2010 & Asia & Together As One & Mental Health & https://fellows.echoinggreen.org/fellow/deepa-gangwani/ \\
\hline Isaac Holeman & 2010 & North America & Medic Mobile & $\begin{array}{l}\text { General Healthcare, Pregnancy \& } \\
\text { Infant Care }\end{array}$ & https//fellows.echoinggreen.org/fellow/isaac-holeman/ \\
\hline Kennedy Odede & 2010 & Africa & Shining Hope for Communities & $\begin{array}{l}\text { Community Hygiene \& Wellhess; Girl } \\
\text { Care }\end{array}$ & https//fellows.echoinggreen org/fellow/kennedy-odede/ \\
\hline Angie Beatty & 2009 & North America & The J.U.I.C.E. Project & General Wellness & https//fellows.echoinggreen.org/fellow/angie-beatty/ \\
\hline Barbara Bush & 2009 & North America & Global Health Corps & $\begin{array}{l}\text { Young Health Professionals } \\
\text { Empowerment }\end{array}$ & https:/fellows.echoinggreen org/fellow/barbara-bush/ \\
\hline Julie Carney & 2009 & North America & Gardens for Health International & Malnutrition & https//fellows.echoinggreen.org/fellow/julie-carney/ \\
\hline Anne Tamar-Mattis & 2008 & North America & inter $\mathrm{ACT}$ & Intersex Children Wellness & https:/fellows.echoinggreen.org/fellow/anne-tamar-mattis/ \\
\hline Elizabeth Scharpf & 2008 & North America & Sustainable Health Enterprises & Women Healthcare & https://fellows.echoinggreen.org/fellow/elizabeth-scharpf/ \\
\hline Jane Chen & 2008 & North America & Embrace & Infant Care & https $/ /$ fellows echoinggreen org/fellow/jane-chen/ \\
\hline Josh Sommer & 2008 & North America & Chordoma Foundation & Chordoma & https//fellows.echoinggreen org/fellow/josh-sommer/ \\
\hline Nathan Sigworth & 2008 & North America & PharmaSecure & Medicine Authenticity & https://fellows.echoinggreen.org/fellow/nathan-sigworth/ \\
\hline Tahir Amin & 2008 & North America & $\begin{array}{l}\text { Initiative for Medicines, Access \& } \\
\text { Knowledge (I-MAK) }\end{array}$ & Medicine Supply & https//fellows.echoinggreen.org/fellow/tahir-amin/ \\
\hline Gemma Bulos & 2007 & North America & Single Drop for SafeWater & Sanitation \& Hygiene & https://fellows echoinggreen. org/fellow/gemma-bulos/ \\
\hline Nina Dudnik & 2007 & North America & Seeding Labs & $\begin{array}{l}\text { General Healthcare \& Scientists } \\
\text { Empowerment }\end{array}$ & https:/fellows.echoinggreen.org/fellow/nina-dudnik/ \\
\hline Anita Buel & 2005 & North America & Deaf Community Health Worker & Disability Wellness & https://fellows.echoinggreen.org/fellow/anita-buel/ \\
\hline Michael Lwin & 2004 & North America & Koe Koe Tech Co., Ltd. & General Healthcare \& Preganancy & https://fellows.echoinggreen.org/fellow/michael-lwin/ \\
\hline Mimi Kim & 2004 & North America & Creative Interventions & Violence Prevention & https//fellows.echoinggreen.org/fellow/mimi-kim/ \\
\hline Alisa Gilbert & 2002 & North America & Unbroken Circle & Cancer-related health services & https:/fellows.echoinggreen.org/fellow/alisa-gilbert/ \\
\hline Cynthia Willard & 2002 & North America & Utah Health and Human Rights Project & Torture Survivors Wellness & https//fellows.echoinggreen.org/fellow/cynthia-willard/ \\
\hline Damilola Adebiyi & 2000 & Africa & Education as a Vaccine Against AIDS & Cancer Survivor Wellness & https://fellows.echoinggreen. org/fellow/damilola-adebivi/ \\
\hline Kyra Bobinet & 1998 & North America & Vision Youthz & High-risk Children Care & https:/fellows.echoinggreen org/fellow/kyra-bobinet/ \\
\hline Leslie Mansfield & 1997 & North America & Miners Legal Resource Center & Wellness of coal\&uranium miners & https://fellows.echoinggreen org/fellow/leslie-mansfield/ \\
\hline Pamela Collins & 1997 & North America & $\begin{array}{l}\text { Society for Emotional Well-being } \\
\text { Worldwide (SEWW) }\end{array}$ & Mental Health & https:/fellows.echoinggreen.org/fellow/pamela-collins/ \\
\hline R. Bradley Sears & 1997 & North America & HIV Legal Checkup & HIV/AIDS & https://fellows.echoinggreen org/fellow/r-bradley-sears/ \\
\hline Caryn Lubetsky & 1996 & North America & H.E.L.P., Inc & HIV & https//fellows.echoinggreen.org/fellow/caryn-lubetsky/ \\
\hline Marla Bear & 1996 & North America & Native American Advocacy Project & Youth Wellness & https//fellows.echoinggreen.org/fellow/marla-bull-bear/ \\
\hline Cynthia Chandler & 1995 & North America & Justice Now & Former Prisoners Wellness & https://fellows.echoinggreen.org/fellow/cynthia-chandler/ \\
\hline David Auerbach & 1995 & North America & Sanergy & Community Hygiene \& Wellness & https:/fellows echoinggreen .org/fellow/david-auerbach/ \\
\hline Mark Hurwitz & 1995 & North America & $\begin{array}{l}\text { Mental Health Project (MPH) of the } \\
\text { Urban Justice Center }\end{array}$ & Mental Health & https//fellows.echoinggreen.org/fellow/mark-hurwitz/ \\
\hline Michelle McKinley & 1995 & North America & Amazonian Peoples' Resources & Reproductive Health & https//fellows.echoinggreen org/fellow/michelle-mckinley/ \\
\hline Carolyn Bess & 1994 & North America & Outdoor Explorations & Disability Wellness & https://fellows.echoinggreen org/fellow/carolyn-bess/ \\
\hline Samuel Myers & 1994 & North America & The Pendeba Project & Public Health & https $/ /$ fellows.echoinggreen.org/fellow/samuel-mvers/ \\
\hline Eric Rosenthal & 1993 & North America & Disability Rights International & Disability Rights and Wellness & https//fellows. echoinggreen. org/fellow/eric-rosenthal \\
\hline Laurel MacLaren & 1993 & Asia & Lentera AIDS Service & HIV/AIDS & https:/fellows.echoinggreen org/fellow/laurel-maclaren \\
\hline Marta Heilbrun & 1993 & North America & Project Concern International & Water \& Malnutrition & https//fellows.echoinggreen.org/fellow/marta-heilbrun/ \\
\hline Uttara Bharath Kumar & 1993 & Asia & Nalamdana & Reproductive Health \& Gender & https:/ fellows.echoinggreen org/fellow/uttara-bharath-kumar/ \\
\hline Cheryl Dorsey & 1992 & North America & Family Van & Healthcare of Vulnerable People & https://fellows.echoinggreen.org/fellow/cheryl-1-dorsey/ \\
\hline Heather Harker & 1992 & North America & The Kuala Lumpur Society for the & Disability Wellness & https://fellows.echoinggreen.org/fellow/heather-harker/ \\
\hline Mike Lynn & 1992 & North America & Chagas' Disease Education Program & Disease Transmission & https:/fellows. echoinggreen. org/fellow/mike-lynn/ \\
\hline John Stelling & 1991 & North America & WHONET & Hospital Efficiency & https//fellows.echoinggreen.org/fellow/iohn-stelling// \\
\hline
\end{tabular}




\begin{tabular}{|c|c|c|c|c|c|}
\hline Amina Laraki Slaoui & 2015 & Africa & Groupe AMH & Disabilities & https://www.schwabfound.org/awardees/amina-laraki-slaoui \\
\hline Antonio Boschini & 2015 & Europe & San Patrignano Community & Drug Addiction & https://www.schwabfound.org/awardees/antonio-boschini \\
\hline Carlos Orellana Aguilar & 2015 & North America & Salauno & Eye Care & https://www.schwabfound.org/awardees/carlos-orellana-aguilar \\
\hline Ernest Darkoh & 2015 & North America & BroadReach Healthcare & Healthcare Improvement \& HIV & https://www.schwabfound.org/awardees/ernest-darkoh \\
\hline Jen Hyatt & 2015 & Europe & Big White Wall & Mental Health & https://www.bigwhitewall.com/ \\
\hline John Sargent & 2015 & North America & BroadReach Healthcare & General Healthcare & https://www.schwabfound.org/awardees/iohn-sargent \\
\hline Jung-Hyeon Kim & 2015 & Asia & Delight & Hearing Aids & https://www.schwabfound.org/awardees/ung-hyeon-kim \\
\hline Kristin Groos Richmond & 2015 & North America & Revolution Foods & Malnutrition & https://www.schwabfound.org/awardees/kristin-groos-richr \\
\hline Mark Arnoldy & 2015 & North America & Possible & $\begin{array}{l}\text { General Healthcare \& Healthcare } \\
\text { Quality }\end{array}$ & https://www.schwabfound.org/awardees/mark-arnoldy \\
\hline Pierre Issa & 2015 & Asia & Arcenciel & General healthcare \& Disabilities & https://www.schwabfound. org/awardees/pierre-issa \\
\hline Sudarshan Hanumappa & 2015 & Asia & Karuna Trust & $\begin{array}{l}\text { General Healthcare \& Healthcare } \\
\text { quality }\end{array}$ & https://www.schwabfound.org/awardees/sudarshan-hanumappa \\
\hline Chris Underhill & 2014 & Europe & citiesRISE & Women Wellness & https://www.schwabfound org/awardees/chris-underhill \\
\hline $\begin{array}{l}\text { Frank Beadle de } \\
\text { Palomo }\end{array}$ & 2014 & Africa & Mothers2mothers & HIV & https://www.schwabfound.org/awardees/frank-beadle-de-palom \\
\hline Javier Lozano & 2014 & North America & Clinicas del Azúcar & Diabetes & https://www.schwabfound.org/awardees/javier-lozano \\
\hline Marc Freedman & 2014 & North America & Encore & Aging & https://www.schwabfound.org/awardees/marc-freedman \\
\hline Merula Steagall & 2014 & South America & $\begin{array}{l}\text { Associação Brasileira de Linfoma e } \\
\text { Leucemia (ABRALE) }\end{array}$ & $\begin{array}{l}\text { General Healthcare \& Healthcare } \\
\text { Improvement }\end{array}$ & https://www.schwabfound.org/awardees/merula-steagall \\
\hline Shelly Batra & 2014 & Asia & $\begin{array}{l}\text { Operation ASHA - Fighting } \\
\text { Tuberculosis Worldwide }\end{array}$ & Tuberculosis \& General Healthcare & https:/www.schwabfound.org/awardees/shelly-batra \\
\hline Bedriye Hulya & 2013 & Europe & $\begin{array}{l}\text { B-fit Sport and Health Living Centers } \\
\text { for Women }\end{array}$ & Mental Health & $\underline{h t t p s: / / w w w . s c h w a b f o u n d . o r g / a w a r d e e s / b e d r i v e-h u l v a ~}$ \\
\hline Chuck Slaughter & 2013 & North America & Living Goods & $\begin{array}{l}\text { General Healthcare, Pregnancy \& } \\
\text { Infant Care }\end{array}$ & $\underline{\text { https: } / / \text { www.schwabfound.org/awardees/chuck-slaughter }}$ \\
\hline Jane Marie Chen & 2013 & North America & Embrace Innovations & Infant care & https://www.schwabfound.org/awardees/jane-marie-chen \\
\hline Rebecca D. Onie & 2013 & North America & Health Leads & Healthcare improvement & https://www.schwabfound_org/awardees/rebecca-d-onie \\
\hline Paul Scott Matthew & 2012 & Africa & North Star Alliance & $\begin{array}{l}\text { General Healthcare, First-Aid \& } \\
\text { Sexual Health }\end{array}$ & https://www.schwabfound org/awardees/paul-scott-matthew \\
\hline $\begin{array}{l}\text { Philip Gregory Van } \\
\text { Kirk }\end{array}$ & 2012 & Central America & Community Empowerment Solutions & Rural Empowerment & https://www.schwabfound.org/awardees/philip-gregory-var \\
\hline Runa Khan & 2012 & Asia & Friendship Bangladesh & Ambulance services \& Primary Care & https $/ /$ www.schwabfound.org/awardees/runa-khan \\
\hline Asher Hasan & 2011 & Asia & Naya Jeevan & General Healthcare \& Infant care & https://www.schwabfound org/awardees/asher-hasan \\
\hline Darell Hammond & 2011 & North America & KaBOOM! & Children Wellness & https//www.schwabfound.org/awardees/darell-hammond \\
\hline $\begin{array}{l}\text { Gisela Maria Bernardes } \\
\text { Solymos }\end{array}$ & 2011 & South America & $\begin{array}{l}\text { CREN Centre of Nutritional Recovery } \\
\text { and Education }\end{array}$ & Malnutrition & https://www.schwabfound_org/awardees/gisela-maria-bernardes \\
\hline Masa Kogure & 2011 & Asia & Table for Two International & Malnutrition \& Community Health & https://www.schwabfound.org/awardees/masa-kogure \\
\hline Roberto Kikawa & 2011 & South America & $\begin{array}{l}\text { Centro de Integracao de Educacao e } \\
\text { Saude - CIES }\end{array}$ & General Healthcare & http://www.ciesglobal.org/ \\
\hline Tomas Sanabria & 2011 & South America & Maniapure & General Healthcare & https://www.schwabfound.org/awardees/tomas-sanabria \\
\hline Antonio Meloto & 2010 & Asia & Gawad Kalinga (GK) & General Healthcare & https://www.schwabfound_org/awardees/antonio-meloto \\
\hline David Gaus & 2010 & North America & Andean Health and Development & Healthcare Improvement & https://www.schwabfound org/awardees/david-gaus \\
\hline Kovin Naidoo & 2010 & Africa & Vision Impact Institute & Eye Care & https://visionimpactinstitute.org/people/kovin-naidoo/ \\
\hline Sakena Yacoobi & 2010 & North America & Afghan Institute of Learning & Pregnancy Care \& General & https://www.schwabfound.org/awardees/sakena-yacoobi \\
\hline Diskul Disnadda & 2009 & Asia & Doi Tung Development Project & General Healthcare \& Drug Addiction & https://www.schwabfound_org/awardees/diskul-dispanadda \\
\hline Dája Kabátová & 2009 & Europe & Letohrádek Vendula & Handicaps & https://www.schwabfound org/awardees/daja-kabatova \\
\hline Flavian Mucci Gaglili & 2009 & Central America & Agape Association & $\begin{array}{l}\text { Disabilities \& Community } \\
\text { Empowerment }\end{array}$ & https:/www.schwabfound.org/awardees/flavian-mucci-gaglili \\
\hline Rajendra Joshi & 2009 & Asia & Saath Livelihood Services & $\begin{array}{l}\text { Children Wellness, Malnutrition, } \\
\text { Sanitation \& Living Condition } \\
\text { Improvement }\end{array}$ & $\underline{h t t p s} / /$ wwww.schwabfound.org/awardees/rajendra-joshi \\
\hline Sébastien Marot & 2009 & Asia & Friends-International & Child \& Youth Protection & https $/ /$ www.schwabfound.org/awardees/sebastien-marot \\
\hline Thilo Bode & 2009 & Europe & Foodwatch & Food Safety & https://www.schwabfound_org/awardees/thilo-bode \\
\hline Csaba Kovács & 2008 & Europe & Félúton Alapitvány & Alcohol \& Drug Addiction & https://www.schwabfound.org/awardees/csaba-kovacs \\
\hline Bart Weetjens & 2007 & Europe & HeroRAT & Tuberculosis & https $/ /$ www.schwabfound org/awardees/bart-weetiens \\
\hline Bitha Piamenta & 2007 & Asia & Kav-Or & Hospitalized Children Care & https://www. schwabfound org/awardees/bilha-piamenta \\
\hline Cosmas I. Okoli & 2006 & Africa & $\begin{array}{l}\text { Mobility Aid and Appliances Research } \\
\text { and Development Centre }\end{array}$ & Disabilities & https $/ /$ www.schwabfound org/awardees/cosmas-i-okoli \\
\hline Erzsébet Szekeres & 2006 & Europe & Alliance for Rehabilitation & Disabilities & https://www.schwabfound.org/awardees/erzsebet-szekeres \\
\hline Jorge G. Gronda & 2006 & Central Americaa & Centro Ginecologico Integral & Women \& Children care & https://www.schwabfound org/awardees/jorge-g-gronda \\
\hline Rut Kolinská & 2006 & Europe & Network of Mother Centers & Mother-children Care & https $/ /$ www.schwabfound.org/awardees/rut-kolinska \\
\hline Yuval Wagner & 2006 & Asia & Access Israel & Disabilities & https://www.schwabfound org/awardees/yuval-wagner \\
\hline Cristóbal Colón & 2005 & Europe & La Fageda & Mental Health & https://www.schwabfound org/awardees/cristobal-colon \\
\hline Andrea Coleman & 2004 & Europe & Riders for Health & General healthcare & https:/www.schwabfound.org/awardees/andrea-coleman \\
\hline Thulasiraj Ravilla & 2004 & Asia & Aravind Eye Care System (AECS) & Eye Care & https:/www.schwabfound.org/awardees/thulasirai-ravilla \\
\hline Rick Surpin & 2003 & North America & $\begin{array}{l}\text { Independence Care System (ICS) } \\
\text { Model }\end{array}$ & $\begin{array}{l}\text { Disabilities \& Injuries care \& General } \\
\text { healthcare }\end{array}$ & https:/www.schwabfound.org/awardees/rick-surpin \\
\hline Richard Jefferson & 2002 & North America & The Lens & Patent Protection & https://www.schwabfound.org/awardees/richard-jefferson \\
\hline Sergii Kostin & 2002 & Europe & Way Home & HIV/AIDS \& Street C & https://www.schwabfound.org/awardees/sergil-kostin \\
\hline David Green & 2001 & Asia & Aravind Eye Care System (AECS) & Eye Care & https://www.schwabfound.org/awardees/david-green \\
\hline Fazle Hasan Abed & 2001 & Asia & BRAC & Child Education \& Wellness & https://www.schwabfound org/awardees/fazle-hasan-abed \\
\hline Joseph Madiath & 2001 & Asia & Gram Vikas & Sanitation & https:/www.schwabfound org/awardees/ioseph-madiath \\
\hline Mechai Viravaidya & 2001 & Asia & $\begin{array}{l}\text { Population and Community } \\
\text { Development Association (PDA) }\end{array}$ & Family Planning & https:/www.schwabfound.org/awardees/mechai-viravaidya \\
\hline Shobha Arole & 2001 & Asia & $\begin{array}{l}\text { Comprehensive Rural Health Project } \\
\text { (CRHP) }\end{array}$ & $\begin{array}{l}\text { Disabiltiy Wellness \& General } \\
\text { healthcare }\end{array}$ & https://www.schwabfound. org/awardees/shobha-arole \\
\hline Vera R. Cordeiro & 2001 & South America & Associação Saúde Criança & $\begin{array}{l}\text { Child care, family planning \& Mental } \\
\text { health }\end{array}$ & https://www.schwabfound.org/awardees/vera-r-cordeiro \\
\hline
\end{tabular}




\begin{tabular}{|c|c|c|c|c|c|}
\hline Fabrice Hégron & 2015 & Asia & En Direct Des Eleveurs & Milk & https:/www.ashoka. org/en/fellow/ fabrice-hegron \\
\hline Jérémy Lachal & 2015 & Europe & Bibliothèques Sans Frontières & Education & https://www.ashoka.org/en/fellow/jeremy-lachal \\
\hline Saifuddin Ahmed & 2015 & Asia & Work for a Better Bangladesh Trust & Tabocco Control & https://www.ashoka.org/en/fellow/saifuddin-ahmed \\
\hline Sasha Kramer & 2015 & Central America & Sustainable Organic Integrated & Sanitation & https $/ /$ www.ashoka.org/en/fellow/sasha-kramer \\
\hline Megan Mukuria & 2014 & Africa & Zana Africa & Reproductive health \& Education & https://www.ashoka.org/en-us/fellow/megan-mukuria \\
\hline Andrea Coleman & 2014 & Europe & Riders for Health & General Healthcare & https://www.ashoka.org/en/fellow/andrea-coleman \\
\hline Bagus Utomo & 2014 & Asia & Yayasan Peduli Skizofrenia Indonesia & Mental Health & https://www.ashoka.org/en/fellow/bagus-utomo \\
\hline Christine Du Preeze & 2014 & Africa & Hlokomela Training Trust (HTT) & General Healthcare & https:/www.ashoka.org/en/fellow/christine-du-preeze \\
\hline Silke Mader & 2014 & Europe & $\begin{array}{l}\text { EFCNI European Foundation for the } \\
\text { Care of Newborn Infants }\end{array}$ & Infant Care & https:/www.ashoka.org/en/fellow/silke-mader \\
\hline Kevin Lee & 2014 & Asia & A Single Drop For Safe Water & Community Hygiene \& Development & https:/www.ashoka.org/en-1/fellow/kevin-lee \\
\hline Bénédicte Défontaines & 2013 & Europe & Réseau mémoire Aloîs & $\begin{array}{l}\text { General Healthcare \& Cognitive } \\
\text { degradation }\end{array}$ & https $/ /$ www.ashoka.org/en/fellow/benedicte-defontaines \\
\hline Lisa Brown & 2013 & North America & Workman Arts & Mental Health & https://www.ashoka.org/en/fellow/lisa-brown \\
\hline Lobe Cissokho & 2013 & Africa & Mutuelle de Santé Oyofal Paj de & General Healthcare & https:/www.ashoka.org/en/fellow/lobe-cissokho \\
\hline Mary Delano & 2013 & South America & México Tierra de Amaranto & Malnutrition & https://www.ashoka.org/en/fellow/mary-delano \\
\hline Charlie Howard & 2012 & North America & MAC-UK & Mental Health & https:/www.ashoka.org/en/fellow/charlie-howard \\
\hline Jason F. Mclennan & 2012 & North America & International Living Building Institute & Green Building & https $/ /$ www.ashoka.org/en/fellow/jason-mclennan \\
\hline Latha Anantha & 2012 & Asia & River Research Centre & Envrionmental sustainability & https:/www.ashoka.org/en/fellow/latha-anantha \\
\hline Martin Guzman & 2012 & South America & Proyecto Lumen & Eye Care & https:/www.ashoka.org/en/fellow/martin-guzman \\
\hline Mohamed Zaazoue & 2012 & Africa & Healthy Egyptians & $\begin{array}{l}\text { Preventive medicine \& healthcare } \\
\text { quality improvement }\end{array}$ & https:/www.ashoka.org/en/fellow/mohamed-zaazoue \\
\hline Nattaya Boonpakdee & 2012 & Asia & Women's Health Advocacy Foundation & Sexual Health \& Youth care & https:/www.ashoka.org/en/fellow/nattaya-boonpakdee \\
\hline Simon Kabore & 2012 & Africa & Network Access to Essential & Healthcare quality improvement & https //www.ashoka.org/en-bd/fellow/simon-kabore \\
\hline Partap Chauhan & 2012 & Asia & Jiva Ayurveda & General Healthcare & https://www.ashoka.org/en/fellow/partap-chauhan \\
\hline Suresh Kumar & 2012 & Asia & Institute of Palliative Medicine & Palliative Care & https//www.ashoka.org/en/fellow/suresh-kumar \\
\hline Zoe Finch Totten & 2012 & North America & The Full Yield & Healthy Lifestyle & https:/www. ashoka.org/en/fellow/zoe-finch-totten \\
\hline Sehnaz Layikel & 2012 & Europe & $\begin{array}{l}\text { RUSIHAK - Human Rights in Mental } \\
\text { Health Initiative }\end{array}$ & Mental Health & $\underline{\text { https } / / \text { www.ashoka.org/en-sg/fellow/sehnaz-layikel }}$ \\
\hline Asher Hasan & 2011 & North America & Naya Jeevan & Health insurance & https:/www.ashoka.org/en/fellow/asher-hasan \\
\hline Catalina Escobar & 2011 & South America & The Juan Felipe Gómez Escobar & Infant \& child care & https://www.ashoka.org/en/fellow/catalina-escobar \\
\hline Gary Cohen & 2011 & North America & Health Care Without Harm & Environmentally-friendly Healthcare & https:/www.ashoka.org/en/fellow/gary-cohen \\
\hline Josh Nesbit & 2011 & North America & Medic Mobile & General Healthcare & https $/ /$ www. ashoka. org/en/fellow/josh-nesbit \\
\hline Kristin Groos Richmond & 2011 & North America & Revolution Foods & Malnutrition & https://www.ashoka.org/en/fellow/kristin-richmond \\
\hline Nimit Tienudom & 2011 & Asia & AIDS Access Foundation & HIV/AIDS & https:/www.ashoka. org/en/fellow/nimit-tienudom \\
\hline Robert Master & 2011 & North America & Commonwealth Care Alliance & $\begin{array}{l}\text { HIV, Disabilities \& General } \\
\text { Healthcare }\end{array}$ & $\underline{\text { https } / / \text { www. ashoka.org/en/fellow/robert-master }}$ \\
\hline Roberto Kikawa & 2011 & South America & $\begin{array}{l}\text { Centro de Integracao de Educacao e } \\
\text { Saude - CIES }\end{array}$ & General Healthcare & $\underline{\text { https://www.ashoka.org/en/fellow/roberto-kikawa }}$ \\
\hline Ana Lucia Villela & 2010 & South America & Projecto Criança e Consumo & Consumerism \& Children development & https://www.ashoka.org/en/fellow/ana-lucia-villela \\
\hline Barry Zuckerman & 2010 & North America & National Center for Medical Legal & General Healthcare & https $/ /$ www.ashoka.org/en/fellow/barry-zuckerman \\
\hline Michel Nischan & 2010 & North America & Wholesome Wave & Farmer Wellness & https:/www. ashoka.org/en/fellow/michel-nischan \\
\hline Paula Johns & 2010 & South America & Adaptare & Tobacco Control & https://www.ashoka.org/en/fellow/paula-johns \\
\hline Samuel Warrack Goldm: & l: 2010 & Asia & D.light & Envrionmental Sustainability & https:/www.ashoka.org/en/fellow/samuel-warrack-goldman \\
\hline Tobias Leenaert & 2010 & Europe & Ethical Vegetarian Association (EVA) & Healthy Food & https:/www.ashoka.org/en/fellow/tobias-leenaert \\
\hline Victor Berrueta & 2010 & North America & $\begin{array}{l}\text { Grupo Interdisciplinario de Tecnologia } \\
\text { Rural Apropiada (GIRA) }\end{array}$ & Environmental Sustainability & https://www.ashoka. org/en/fellow/victor-berrueta \\
\hline Arnold Noyek & 2009 & North America & CISEPO & $\begin{array}{l}\text { Healthcare Provider empowerment \& } \\
\text { otolaryngology }\end{array}$ & https://www.ashoka.org/en/fellow/arnold-noyek \\
\hline Jean-François Archamb: & p:2009 & North America & Band of Chefs & Malnutrition & https $/ /$ www.ashoka.org/en/fellow/jean-francois-archambault \\
\hline Gregory Van Kirk & 2008 & Central America & The New Development Solutions Group & General Healthcare & https $\mathrm{J} / \mathrm{www}$.ashoka.org/en/fellow/gregory-van-kirk \\
\hline Kiran Bir Sethi & 2008 & Asia & Riverside School & Child Development & https://www.ashoka.org/en/fellow/kiran-bir-sethi \\
\hline Molly Barker & 2008 & North America & Girls on the Run & Women Wellness & https:/www.ashoka.org/en/fellow/molly-barker \\
\hline Rebecca D. Onie & 2008 & North America & Health Leads & General Healthcare & https//www.ashoka.org/en/fellow/rebecca-onie \\
\hline Daniel C. Ross & 2007 & North America & Nuestras Raices & Community Empowerment & https://www.ashoka.org/en/fellow/daniel-ross \\
\hline Princess Olufemi-Kayod & d 2007 & Africa & Media Concern for Women and & Sexually abused children & https:/www.ashoka.org/en/fellow/princess-olufemi-kayode \\
\hline Jean-Michel Ricard & 2006 & Europe & SIEL Bleu & Elderly care & https://www.ashoka.org/en-us/fellow/iean-michel-ricard \\
\hline Ananya Raihan & 2004 & Asia & D.Net & Rural Empowerment & https:/www.ashoka.org/en/fellow/ananya-raihan \\
\hline Satyan Mishra & 2004 & Asia & Drishtee & Rural Empowerment & https:/www.ashoka.org/en/fellow/satyan-mishra \\
\hline Jeff Palmer & 2003 & North America & Coordinated Care Network & General Healthcare & $\underline{\text { https: } / / \text { www.ashoka.org/en/fellow/ieff-palmer }}$ \\
\hline Renae Griggs & 2003 & North America & $\begin{array}{l}\text { National Police Family Violence } \\
\text { Prevention Initiative }\end{array}$ & Mental Health & $\underline{\text { https:/www.ashoka.org/en/fellow/renae-griggs }}$ \\
\hline Rita Sembuya & 2003 & Africa & Joyce Fertility Support Center & Infertility & https:/www.ashoka.org/en/fellow/rita-sembuya \\
\hline Zackie Achmat & 2003 & Africa & Treatment Action Campaign & HIV/AIDS & https:/www.ashoka. org/en/fellow/zackie-achmat \\
\hline David Erickson & 2001 & North America & Samaritan Inns, Inc. & Drug Addiction & https:/www.ashoka.org/en/fellow/david-erickson \\
\hline Carlos Gómez & 1998 & North America & $\begin{array}{l}\text { Instituto Mexicano de Medicina } \\
\text { tradicional Tlahili }\end{array}$ & $\begin{array}{l}\text { Prenatal care, child health \& Primary } \\
\text { care }\end{array}$ & $\underline{\text { https://www. ashoka.org/en/fellow/carlos-vargas-gomez }}$ \\
\hline Albina Ruiz & 1996 & South America & Ciudad Saludable & Garbage processing & https://www.ashoka.org/en/fellow/albina-ruiz \\
\hline Indu Harkrishanlal Capo & o 1992 & Asia & CHETNA & Women care \& General Healthcare & https:/www.ashoka.org/en/fellow/indu-capoor \\
\hline Teresa Zorrilla Palomar & 1990 & North America & Health in the Hands of the People & Healthcare Improvement & https://www.ashoka.org/en/fellow/teresa-zorrilla-palomar \\
\hline
\end{tabular}

